Tomasz Katużny ${ }^{1}$

\title{
PROCEDURA ZATWIERDZANIA TABEL WYNAGRODZEŃ ZA KORZYSTANIE Z UTWORÓW LUB PRZEDMIOTÓW PRAW POKREWNYCH Z PERSPEKTYWY NOWOCZESNEGO ROZSTRZYGANIA SPORÓW
}

\section{Tabele wynagrodzeń $z$ utworów lub przedmiotów praw pokrewnych - uwagi ogólne}

Zasady procedowania $\mathrm{w}$ przedmiocie zatwierdzania tabel wynagrodzeń z utworów lub przedmiotów praw pokrewnych $\mathrm{w}$ ramach postępowania prowadzonego przez zespół orzekający Komisji Prawa Autorskiego określone zostały w obowiązujących regulacjach w przepisach ustawy z dnia 4 lutego 1994 r. o prawie autorskim i prawach pokrewnych ${ }^{2}$ (dalej: ustawa o prawie autorskim). Zgodnie $\mathrm{z}$ art. $110^{1}$ ust. 1 pr. aut. Komisja Prawa Autorskiego (dalej: Komisja) jest organem władzy publicznej powoływanym przez ministra właściwego do spraw kultury i dziedzictwa narodowego celem realizacji zadań określonych przepisami ustawy o prawie autorskim. Skład Komisji, zasady działania i kompetencje zostały wskazane w przepisach rozdziału 12. ustawy o prawie autorskim, które to przepisy wprowadzono nowelizacją ustawy dokonaną ustawą z dnia 8 lipca 2010 r. o zmianie ustawy o prawie autorskim i prawach pokrewnych oraz ustawy o kosztach sądowych w sprawach cywilnych. ${ }^{3}$ Nowelizacja była konsekwencją wyroku Trybunału Konstytucyjnego z dnia 24 stycznia 2006 r., ${ }^{4}$ w którym to wyroku za niezgodny z Konstytucją Rzeczypospolitej Polskiej uznany został art. 108 ust. 3 pr. aut. dotyczący postępowania przed Komisją w kwestii zatwierdzenia przedstawionych przez organizację zbiorowego zarządzania tabel wynagrodzeń za korzystanie z utworów lub artystycznych wykonań.

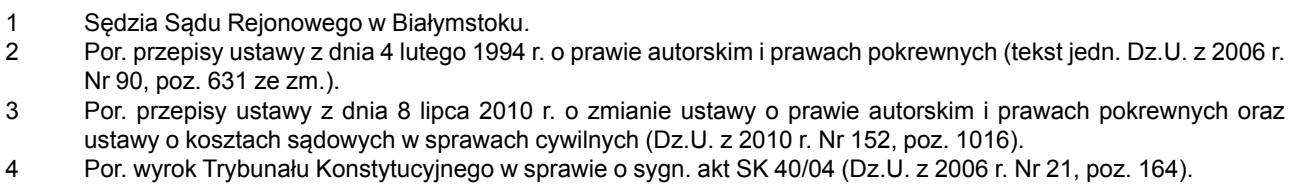


Zarówno w przepisach w dotychczasowym brzemieniu, jak też w regulacjach aktualnie obowiązujących ustawodawca precyzyjnie wskazał, iż do zadań Komisji należy między innymi rozpatrywanie spraw o zatwierdzanie i zmianę zatwierdzonych tabel wynagrodzeń za korzystanie $\mathrm{z}$ utworów lub przedmiotów praw pokrewnych. ${ }^{5}$ Realizacja tego zadania odbywa się zgodnie z art. $110^{11} \mathrm{i}$. pr. aut. zasadniczo $\mathrm{w}$ dwóch etapach, mianowicie opracowania otwartej propozycji tabel ${ }^{6}$ przez organizację zbiorowego zarządzania prawami autorskimi oraz zatwierdzenie przedstawionego projektu w ramach postępowania przed Komisją. Organizacje zbiorowego zarządzania reprezentujące autorów praw opracowują tabele wynagrodzeń w ramach realizacji statutowego zadania zbiorowego zarządzania i ochrony powierzonych im praw autorskich lub praw pokrewnych zgodnie z art. 104 i n. pr. aut. Tabele wynagrodzeń za korzystanie $\mathrm{z}$ utworów lub przedmiotów praw pokrewnych korespondują $\mathrm{z}$ ustalonym ustawą o prawie autorskim obowiązkiem stosowania stawek $\mathrm{z}$ tabel $\mathrm{w}$ umowach zawieranych przez organizacje zbiorowego zarządzania prawami autorskimi z użytkownikami praw. Stawki wynagrodzeń określone w ustalonych tabelach mają więc istotne znaczenie w „obrocie” prawami autorskimi, bowiem zawierane umowy nie mogą przewidywać stawek niższych niż określone w tabeli. ${ }^{7}$ Organizacje zbiorowego zarządzania reprezentujące interesy twórców oraz użytkownicy korzystający z praw autorskich lub praw pokrewnych zawierają więc umowy odpowiednio, przy wykorzystaniu stawek określonych w tabelach wynagrodzeń zatwierdzonych $w$ ramach realizacji trybu postępowania publicznoprawnego zgodnie z przepisami ustawy o prawie autorskim.

W powołanym wyroku Trybunału Konstytucyjnego nie została zakwestionowana materia dotycząca istotności i znaczenia stawek wynagrodzeń określonych w tabelach dla zawieranych umów dotyczących obrotu prawami autorskimi. Podobnie nie podważono działalności na rynku organizacji zbiorowego zarządzania (również w ramach wnioskowania o zatwierdzenie tabel), ani też nie został zakwestionowany status Komisji dokonującej zatwierdzenia tabel wynagrodzeń za korzystanie z utworów lub przedmiotów praw pokrewnych. Przedmiotem rozważań i rozstrzygnięcia Trybunału Konstytucyjnego stała się natomiast regulacja dotycząca postępowania przed Komisją i to wyłącznie w zakresie pozbawienia kwestionowanymi przepisami możliwości uczestniczenia w tym postępowaniu $\mathrm{w}$ charakterze strony użytkowników korzystających z utworów lub przedmiotów praw pokrewnych.

Por. G. Materna, Antymonopolowa ocena wysokości stawek wynagrodzeń za korzystanie z utworów lub przedmiotów praw pokrewnych w świetle znowelizowanego prawa autorskiego. Teza nr 3, „Przegląd Ustawodawstwa Gospodarczego" 2013, nr 4, s. 28-36.

6 Por. odnośnie określenia propozycji tabel otwartą ofertą, a nie projektem J.Błeszyński, Komentarz do wyroku TK z dnia 24 stycznia 2006 r., SK 40/04. Teza 4, „Przegląd Ustawodawstwa Gospodarczego” 2006, nr 8, s. 10.

Por. E. Ferenc-Szydełko (red.), Ustawa o prawie autorskim i prawach pokrewnych. Komentarz, Warszawa 2014, System Informacji Prawnej Legalis 2015, komentarz do art. $110^{16}$, t. 1. 
Procedura zatwierdzania tabel wynagrodzeń za korzystanie z utworów...

Regulacje wprowadzone powołaną wyżej zmianą ustawy o prawie autorskim określają tryb postępowania w przedmiocie zatwierdzenia tabel wynagrodzeń za korzystanie z utworów lub przedmiotów praw pokrewnych zgodnie z oceną przedmiotowych przepisów dokonaną powołanym wyżej wyrokiem Trybunału Konstytucyjnego. Obowiązujące przepisy przewidują zatem określenie zakresu procedowania przed Komisją celem zatwierdzenia stawek zaproponowanych przez organizację zbiorowego zarządzania $\mathrm{z}$ zagwarantowaniem możliwości kontynuacji przedmiotowego postępowania przed sądem powszechnym w przypadku kwestionowania decyzji Komisji. W obowiązujących przepisach podkreślono, że postępowanie w przedmiocie zatwierdzenia tabel prowadzone jest zgodnie z przepisami Kodeksu postępowania cywilnego o postępowaniu nieprocesowym. Ponadto obowiązujące regulacje precyzyjnie określają uczestników przedmiotowego postępowania z zagwarantowaniem wezwania do udziału w sprawie zainteresowanych podmiotów przez obowiązek dokonania stosownego ogłoszenia w dziennikach o zasięgu ogólnopolskim oraz w Biuletynie Informacji Publicznej.

\section{Specyfika procedury zatwierdzania tabel wynagrodzeń z utworów lub przedmiotów praw pokrewnych}

Zgodnie z przepisami ustawy o prawie autorskim, mianowicie art. $110^{11}$ ust. 1 pr. aut. sprawy o zatwierdzanie tabel wynagrodzeń za korzystanie z utworów lub przedmiotów praw pokrewnych rozpatruje zespół orzekający Komisji w składzie pięcioosobowym. Zgodnie z art. $110^{11}$ ust. 2-4 pr. aut. skład zespołu orzekającego ustalany jest przez przewodniczącego Komisji z grona trzydziestu arbitrów powołanych w trybie ustawy (art. $110^{2}$ pr. aut.), przy czym arbitrzy wskazywani są z czterech grup środowisk (odpowiednio reprezentujących twórców i użytkowników korzystających z praw) uprawnionych do zgłaszania kandydatów do Komisji. Nadto w trybie określonym w tych przepisach wyznaczeni arbitrzy dokonują wyboru przewodniczącego zespołu orzekającego Komisji z listy arbitrów Komisji, a jeżeli wyznaczeni arbitrzy Komisji nie dokonają wyboru przewodniczącego zespołu orzekającego Komisji, zostanie on wyznaczony przez przewodniczącego Komisji.

Ustalenia składu zespołu orzekającego Komisji według zasad określonych w powołanych przepisach ma istotne znaczenie, przy uwzględnieniu okoliczności, iż zespół orzekający Komisji, będącej organem publicznym ustalany jest zgodnie z zasadą reprezentatywności składu Komisji. Fakt ten ma ogromne znaczenie dla akceptacji rozstrzygnięć w przedmiocie zatwierdzania tabel wynagrodzeń przez mających zasadniczo rozbieżne interesy uczestników obrotu prawami. Należy przy tym podkreślić, iż zespół orzekający Komisji, a więc każdy z arbitrów wchodzących w skład zespołu, winien realizować czynności związane z zatwierdzaniem tabel zgodnie 
z prawem i w poczuciu interesu publicznego. ${ }^{8}$ Wykluczone zatem jest podejmowanie przez arbitrów jakichkolwiek działań mających na celu zabezpieczenie interesów czy to twórców, czy użytkowników korzystających z praw. Zespół orzekający powinien podejmować decyzje bezstronnie i niezależnie, z zagwarantowaniem pogłębiania zaufania do organów publicznych. Należy też nadmienić, że zgodnie z art. 110 pr. aut. arbitrzy wchodzący w skład zespołów orzekających Komisji powinni w ramach prowadzenia postępowania dokonywać analizy wysokości wynagrodzeń dochodzonych przez organizacje zbiorowego zarządzania, przy uwzględnieniu wysokości wpływów osiąganych z korzystania z utworów i przedmiotów praw pokrewnych, a także charakter i zakres korzystania $\mathrm{z}$ tych utworów i przedmiotów praw pokrewnych.

Postępowanie w przedmiocie zatwierdzenia tabel wynagrodzeń za korzystanie $\mathrm{z}$ utworów lub przedmiotów praw pokrewnych zgodnie $\mathrm{z}$ art. $110^{12}$ ust. 1 pr. aut. inicjowane jest wnioskiem składanym przez organizację zbiorowego zarządzania. ${ }^{9}$ Zgodnie $\mathrm{z}$ wymogami określonymi w art. $110^{12}$ ust. 4 pr. aut. wniosek powinien zawierać wskazanie pola eksploatacji oraz kategorie utworów lub przedmiotów praw pokrewnych, których dotyczy tabela, a także kategorie podmiotów, na rzecz których wnioskodawca działa oraz wysokość stawek wynagrodzenia. Uczestnikami postępowania $\mathrm{w}$ sprawach o zatwierdzenie tabel wskazani zostali zgodnie $\mathrm{z}$ art. $110^{12}$ ust. 6 pkt 1-3 pr. aut. odpowiednio wnioskodawca, inne organizacje zbiorowego zarządzania, które w udzielonym im zezwoleniu na zbiorowe zarządzanie i ochronę powierzonych im praw autorskich lub praw pokrewnych mają wskazane pola eksploatacji, których dotyczą tabele wynagrodzeń oraz organizacje zrzeszające podmioty korzystające $\mathrm{z}$ utworów lub przedmiotów praw pokrewnych, których działalność obejmuje pola eksploatacji wynikające z tabel wynagrodzeń, jeżeli złożą wniosek o udział $\mathrm{w}$ tym postępowaniu. ${ }^{10}$ Zasadniczo więc przez odniesienie określenia stron postępowania adekwatnie do przepisów postępowania cywilnego o postępowaniu nieprocesowym zrealizowany został postulat równouprawnienia uczestników postępowania w przedmiocie zatwierdzenia tabel. Należy też podkreślić, że z powołanych regulacji wynika prawo udziału w postępowaniu podmiotów korzystających z utworów lub przedmiotów praw pokrewnych bez jakiegokolwiek ograniczenia praw tych podmiotów, pozbawionych możliwości udziału w postępowaniu w poprzednim stanie prawnym przed nowelizacją omawianych przepisów dokonaną w roku 2010. $\mathrm{O}$ transparentności analizowanych regulacji gwarantujących udział w postępowaniu zainteresowanych podmiotów przesądza określony w art. $110^{12}$ ust. 8 pr. aut. obowiązek przewodniczącego zespołu orzekającego Komisji zamieszczenia ogłosze-

8 Ibidem, komentarz do art. $110^{11}$, t. 1

9 Por. R. Flejszar, M. Malczyk-Herdzina, Postępowanie cywilne w sprawach o zatwierdzanie i o zmianę zatwierdzonych tabel wynagrodzeń za korzystanie z utworów lub przedmiotów praw pokrewnych. Teza nr 6, „Zeszyty Naukowe Uniwersytetu Jagiellońskiego" 2011, z. 111, s. 20-24. 
nia w co najmniej dwóch drukowanych dziennikach o zasięgu ogólnopolskim oraz w Biuletynie Informacji Publicznej na stronie podmiotowej ministra właściwego do spraw kultury i ochrony dziedzictwa narodowego o wszczęciu postępowania w sprawie o zatwierdzenie tabeli wynagrodzeń, wzywającego zainteresowane podmioty do wstępowania do postępowania. Udział więc w charakterze uczestnika w prowadzonym postępowaniu uzależniony jest od złożenia wniosku przez zainteresowanych, z zaznaczeniem, iż w przypadku odmowy dopuszczenia do udziału w sprawie przysługuje zgodnie art. $110^{12}$ ust. 7 pr. aut. zażalenie rozpoznawane w ramach sądowej kontroli prawidłowości procedowania zespołu orzekającego Komisji.

Przepisy regulujące postępowania w zakresie zatwierdzenia tabeli wynagrodzeń precyzyjnie zgodnie $\mathrm{z}$ treścią art. $110^{13}$ ust. 1 pr. aut. określają ograniczenie czasu trwania postępowania do 6 miesięcy, chyba że wszyscy uczestnicy postępowania wyrażą zgodę na określone przedłużenie tego terminu. Należy przy tym nadmienić, iż zgodnie z treścią art. $110^{13}$ ust. 2 pr. aut. w szczególnie uzasadnionych przypadkach, zespół orzekający Komisji może dokonać przedłużenia terminu na dalszy czas oznaczony, niezbędny do wydania orzeczenia w sprawie, przy czym wyłącznie za zgodą uczestników postępowania. Podkreślenia wymaga wskazanie, iż prowadzone postępowanie na podstawie art. $110^{13}$ ust. 3 pr. aut. ulega umorzeniu decyzją zespołu orzekającego Komisji w przypadku niezakończenia postępowania w ustawowo określonym terminie lub terminach przedłużonych za zgodą uczestników postępowania. Omawiane ograniczenie czasowe trwania postępowania należy zatem ocenić jako wyjątkowo dyscyplinujące zespół orzekający Komisji do sprawnego podejmowania czynności, zasadniczo w interesie uczestników postępowania. Sprawność postępowania przy zachowaniu gwarancji jakości staje się wyzwaniem zarówno w działalności podmiotów podejmujących czynności decyzyjne poza systemem sądowniczym, a szczególnie w odniesieniu do decyzyjności orzeczniczej w ramach rozstrzygania sporów. Określenie w obowiązujących regulacjach terminów prowadzenia postępowania ze sprecyzowaniem sankcji w postaci umorzenia postępowania wydaje się być rozwiązaniem nie tylko dyscyplinującym organy orzecznicze, ale również inspirującym uczestników postępowania do aktywnej partycypacji w czynnościach realizowanych w toku postępowania. Zarówno więc spełnienie wymogów formalnych wniosku o zatwierdzenie tabeli wynagrodzeń, jak też precyzyjne i zwięzłe formułowanie stanowisk stron może mieć istotne znaczenie $\mathrm{w}$ zachowaniu określonych ustawowo terminów postępowania, z wykluczeniem ryzyka umorzenia postępowania $w$ razie przekroczenia ustalonych terminów. Należy również podkreślić, iż przepisy ustawy o prawie autorskim zgodnie z treścią art. $110^{14}$ ust. 3 pr. aut. przewidują w przypadku umorzenia postępowania decyzją zespołu orzekającego Komisji możliwość wystąpienia przez wnioskodawcę o zatwierdzenie tabeli przez sąd. Konsekwencją zatem stwierdzenia przewlekłości postępowania przez przekroczenie ustalonych terminów staje się przekazanie sprawy na drogę postępowania sądowego z wyłączeniem postępowania przed zespołem orzekającym Komi- 
sji. Przeniesienie postępowania na poziom sądowego zatwierdzania tabel okazuje się więc najdalej idącym środkiem dyscyplinującym prowadzących postępowanie i biorących w nim udział uczestników postępowania.

Zasadniczym celem postępowania w przedmiocie zatwierdzenia tabel wynagrodzeń za korzystanie $\mathrm{z}$ utworów lub przedmiotów praw pokrewnych pozostaje zgodnie $\mathrm{z}$ treścią art. $110^{13}$ ust. 4 pr. aut. rozstrzygnięcie $\mathrm{w}$ zakresie zatwierdzenia bądź odmowy zatwierdzenia tabel, w całości lub w części. ${ }^{11}$ Rozstrzygnięcie zespołu orzekającego Komisji może być oceniane jako arbitralna decyzja, przy czym należy podkreślić, iż w myśl art. $110^{13}$ ust. $4 \mathrm{zd} .2$ pr. aut. w zakresie, w którym odmówiono zatwierdzenia stawek określonych w tabelach, zespół orzekający Komisji zobowiązany jest przedstawić na piśmie propozycje zmian w przedłożonej do zatwierdzenia tabeli wynagrodzeń, wraz z ich uzasadnieniem. Wskazany obowiązek ma istotne znaczenie dla dalszego postępowania $\mathrm{w}$ sprawie zatwierdzenia tabel, bowiem zgodnie $\mathrm{z}$ art. $110^{13}$ ust. 4 zd. 3 pr. aut. zaproponowane przez zespół orzekających propozycje zmian, przy akceptacji uczestników postępowania, stają się prawomocne. Dokonując merytorycznego rozstrzygnięcia zespół orzekający ma obowiązek wziąć pod uwagę stanowiska uczestników postępowania i zebrany w sprawie materiał dowodowy, ale również zgodnie z treścią art. $110^{13}$ ust. 5 pkt 1-2 pr. aut. również charakter, zakres i wysokość wpływów osiąganych z korzystania z utworów i przedmiotów praw pokrewnych oraz kwotę ogólnego obciążenia podmiotów korzystających z utworów i przedmiotów praw pokrewnych $\mathrm{z}$ tytułu korzystania z praw autorskich i praw pokrewnych na danym polu eksploatacji. ${ }^{12}$ Należy przy tym podkreślić, iż zespół orzekający Komisji przy podejmowaniu rozstrzygnięcia powinien wziąc pod uwagę zgodnie z art. $110^{13}$ ust. 5 pkt 5 pr. aut. również uzasadniony interes społeczny, rozumiany jako wyważenie interesów podmiotów, które zobowiązane będą do stosowania tabeli wynagrodzeń. Zatwierdzone tabele wynagrodzeń podlegają zgodnie z treścią art. $110^{13}$ ust. 7 pr. aut. publikacji przez przewodniczącego Komisji w Biuletynie Informacji Publicznej na stronie podmiotowej ministra właściwego do spraw kultury i ochrony dziedzictwa narodowego.

Obowiązujące przepisy ustawy o prawie autorskim, uwzględniające zmiany wprowadzone w związku z powołanym wyżej wyrokiem Trybunału Konstytucyjnego kwestionującym pozbawienie możliwości udziału w postępowaniu podmiotów reprezentujących interesy korzystających z utworów lub przedmiotów praw pokrewnych przewidują nie tylko regulacje określające możliwość zgłoszenia zainteresowanego do udziału w postępowaniu, ale również przepisy gwarantujące uczestnikom postępowania prowadzonego przed zespołem orzekającym Komisji wystąpienie na drogę postępowania sądowego. Uczestnicy postępowania o zatwier-

\footnotetext{
11 Por. A. Jucewicz, Glosa do wyroku Sądu Najwyższego z dnia 3 stycznia 2007 r., IV CSK 303/06. Teza 1, Glosa 2007/4, s. 93-102.

12 Por. J. Błeszyński, Nowelizacja ustawy o prawie autorskim i prawach pokrewnych z 8 lipca 2010 roku. Teza 5, „Przegląd Ustawodawstwa Gospodarczego” 2011, nr 8, s. 23-32;
} 
dzenie tabel wynagrodzeń, niezadowoleni z orzeczenia zespołu orzekającego Komisji zgodnie art. $110^{14}$ ust. 1 pr. aut. uprawnieni są do złożenia wniosku o przekazanie sprawy o zatwierdzenie tabeli, w całości lub w części przez sąd. Konsekwencją zatem kwestionowania rozstrzygnięcia zespołu orzekającego Komisji przez złożenie stosownego wniosku uczestnika postępowania staje się obowiązek przekazania wniosku wraz z aktami sprawy do rozstrzygnięcia właściwemu sądowi. ${ }^{13}$ Należy również wskazać, iż w przepisach obowiązujących przed zmianą ustawy o prawach autorskich przewidziane było stosowanie przepisów Kodeksu postępowania administracyjnego, ${ }^{14}$ natomiast obowiązujące regulacje w art. $110^{1}$ ust. 3 pr. aut. określają, iż do postępowań prowadzonych przed Komisją stosuje się odpowiednio przepisy Kodeksu postępowania cywilnego o postępowaniu nieprocesowym. Obowiązujące brzmienie przepisów istotnie zmienia zatem sposób i zakres procedowania w ramach postępowania zarówno przed zespołem orzekającym Komisji, jak też postępowania prowadzonego przed sądem powszechnym przez umożliwienie merytorycznej ingerencji w treść zatwierdzanych tabel i zastąpienie kontroli sądowo-administracyjnej odpowiednio możliwością prowadzenia sądowego postępowania przed sądem powszechnym w ramach rozpoznawania sprawy równouprawnionych uczestników postępowania o zatwierdzenie tabel wynagrodzeń z utworów lub przedmiotów praw pokrewnych.

Prowadzenie postępowania przed zespołem orzekającym Komisji zasadniczo powinno kończyć się prawomocnym rozstrzygnięciem i staje się tak zgodnie $\mathrm{z}$ treścią art. $110^{14}$ ust. 4 pr. aut. w razie zakończenia postępowania i akceptacji rozstrzygnięcia przedmiotu postępowania przez biorących w nim udział uczestników. Niezłożenie wniosku przez niezadowolonego uczestnika postępowania skutkuje zatem prawomocnością rozstrzygnięcia zespołu orzekającego Komisji, przy czym zgodnie z art. $110^{14}$ ust. 4 zd. 2 pr. aut. również odpowiednio akceptacji rozstrzygnięcia w części, co do której nie złożono wniosku o zatwierdzenie tabeli przez sąd. Jeszcze raz warto w tym miejscu podkreślić możliwość uprawomocnienia zmian zaproponowanych przez zespół orzekający Komisji w sytuacji odmowy zatwierdzenia wnioskowanych tabel. Ingerencja w merytoryczną treść zatwierdzanych tabel może okazać się konstruktywną inicjatywą zespołu orzekającego Komisji w zakresie przedstawienia propozycji tabel wynagrodzeń, która zostanie zaakceptowana przez uczestników postępowania. Przedstawiony tryb „quasi-uzgodnienia” między organem rozstrzygającym a uczestnikami postępowania $\mathrm{w}$ ramach negatywnego

13 W odniesieniu do wskazania sądu właściwego por. rozporządzenie Ministra Sprawiedliwości z dnia 3 lutego 2011 r. w spawie wyznaczenia sądu okręgowego właściwego do rozpoznania niektórych spraw z zakresu prawa autorskiego i praw pokrewnych (Dz.U. z 2011 r. Nr 36, poz. 186), w którym zgodnie z §1 rozporządzenia wyznaczony został Sąd Okręgowy w Poznaniu, jako właściwy do rozpoznania między innymi spraw o zatwierdzenie tabel wynagrodzeń z utworów lub przedmiotów praw pokrewnych.

Por. uchylony art. 108 ust. 4 ustawy o prawach autorskich w brzmieniu przed zmianą tych regulacji przepisami ustawy z dnia 8 lipca 2010 r. o zmianie ustawy o prawie autorskim i prawach pokrewnych oraz ustawy o kosztach sądowych w sprawach cywilnych (Dz.U. z 2010 r. Nr 152, poz. 1016). 
rozstrzygnięcia w przedmiocie odmowy zatwierdzenia wnioskowanych stawek wynagrodzeń może faktycznie skutkować pozytywnym zakończeniem prowadzonego postępowania przez prawomocne ustalenia tabel wynagrodzeń zgodnie z propozycją zespołu orzekającego Komisji, przy niekwestionowaniu tej propozycji przez uczestników powstępowania. W ramach powołanych wyżej przepisów ustawy o prawie autorskim eksponowany jest więc koncyliacyjny charakter rozwiązywania sporów odpowiednio określony przez możliwość sformułowani propozycji zakończenia postępowania $\mathrm{z}$ akceptacją zamian w zatwierdzanych tabelach zaproponowanych przez zespół orzekający Komisji. Konieczność prowadzenia ewentualnego postępowania sądowego poprzedzona jest więc faktycznie prowadzeniem uprzedniego efektywnego postępowania, w ramach którego poszukiwane są rozwiązania w zakresie zatwierdzenia tabel wynagrodzeń, przy czym inicjatywa aktywności procesowej stron koresponduje z zaangażowaniem arbitrów wchodzących w skład zespołu orzekającego Komisji. Efektywne, skuteczne i aktywne procedowanie przed zespołem orzekającym Komisji może zatem doprowadzić do wykluczenia potrzeby prowadzenia długotrwałego i narażającego strony na ponoszenie znacznych kosztów postępowania sądowego, co przez pryzmat sprawności procedowania leży niewątpliwie $\mathrm{w}$ interesie uczestników postępowania oraz szeroko rozumianego interesu publicznego.

$\mathrm{W}$ przepisach ustawy o prawie autorskim przewidziana została zgodnie art. $110^{15}$ pr. aut. również możliwość zmiany uprzednio zatwierdzonych stawek wynagrodzeń z możliwością wystąpienia przez każdego z uczestników postępowania o zmianę zatwierdzonej tabeli wynagrodzeń, ale wyłącznie w przypadku istotnej zmiany okoliczności stanowiących podstawę orzeczenia w sprawie zatwierdzenia tabeli wynagrodzeń. ${ }^{15}$

\section{Zatwierdzanie tabel wynagrodzeń z utworów lub przedmiotów praw pokrewnych w kontekście koncepcji nowoczesnego rozstrzygania sporów}

Przedstawione zasady prowadzenia postępowania przed zespołem orzekającym Komisji w przedmiocie zatwierdzania tabel wynagrodzeń z utworów lub przedmiotów praw pokrewnych określone zostały w obowiązujących przepisach zmianami ustawy o prawie autorskim, której nowelizacja została niejako wymuszona powołanym wyżej orzeczeniem Trybunału Konstytucyjnego z dnia 24 stycznia 2006 r. Stwierdzona niezgodność przepisu postępowania prowadzonego przez Komisję $\mathrm{w}$ odniesieniu do kwestionowanego pozbawienia użytkowników korzystających z praw możliwości udziału w postępowaniu w charakterze strony wynikała z oczywistego naruszenia zasady pełnej ochrony prawnej gwarantowanej w art. 45 Kon- 
stytucji Rzeczypospolitej Polskiej. ${ }^{16}$ Należy w pełni podzielić stanowisko wyrażone w uzasadnieniu powołanego wyroku Trybunału Konstytucyjnego, iż w ramach prowadzonego postępowania winno być zapewnione umożliwienie stronom zajęcia równoprawnego stanowiska względem zatwierdzanych tabel wynagrodzeń oraz realizacja zagwarantowanej w Konstytucji pełnej ochrony prawnej, w tym również udziału strony w postępowaniu prowadzonym w ramach sądowej kontroli prawidłowości rozstrzygnięcia organu publicznego.

Analizowane obowiązujące przepisy regulujące zasady procedowania w przedmiocie zatwierdzania tabel wynagrodzeń z utworów lub przedmiotów praw pokrewnych zapewniają pełną ochronę praw uczestników postępowania zgodnie ze stanowiskiem Trybunału Konstytucyjnego wyrażonym w powołanym orzeczeniu. W tym kontekście należy wyeksponować przewidzianą w regulacjach ustawy o prawie autorskim możliwość zgłoszenia zainteresowanego do udziału w postępowaniu, czy też określony w analizowanych przepisach tryb realizacji sądowej kontroli rozstrzygnięcia zespołu orzekającego Komisji w ramach postępowania prowadzonego przed sądem powszechnym zgodnie z przepisami Kodeksu postępowania cywilnego o postępowaniu nieprocesowym. Zgodności omawianych przepisów ze standardem zapewnienia ochrony prawnej potwierdzona została również określeniem zasad uprzedniego procedowania w przedmiocie zatwierdzenia tabel wynagrodzeń przed zespołem orzekającym Komisji i zagwarantowaniem w przypadku kwestionowania rozstrzygnięcia Komisji skierowania sprawy na drogę postępowania sądowego. Zasadniczo bowiem postępowanie może być prowadzone przed zespołem orzekającym Komisji z gwarancją zachowania prawa do sądu w ramach realizacji postępowania sądowego przed właściwym sądem. Podobnie za istotną z punktu widzenia realizacji procedur przed zespołem orzekającym Komisji należy uznać pośrednią możliwość decydowania uczestników postępowania w zakresie ustalenia składu zespołu orzekającego. Ponownie jednak warto podkreślić, iż przedstawiona wyżej reprezentatywność składu zespołu orzekającego Komisji nie może służyć równoważeniu przeciwstawnych interesów uczestników postępowania, czy też być wyrazem naruszania podstawowej zasady bezstronności i niezależności arbitrów. Rozstrzyganie sporu przez arbitrów będących przedstawicielami środowisk reprezentujących twórców i użytkowników korzystających z praw ma ogromne i decydujące znaczenie dla akceptacji rozstrzygnięć zespołu orzekającego Komisji oraz pogłębiania zaufania obywateli do obowiązujących sposobów rozstrzygania sporów ukształtowanych na miarę demokratycznego państwa prawa.

Podobnie należy docenić przedstawione rozwiązanie w zakresie określenia czasowego limitu długości prowadzenia postępowania, gwarantującego z jednej strony dyscyplinowanie arbitrów w ramach prowadzenia postępowania, a $\mathrm{z}$ drugiej strony

\footnotetext{
16 Por. art. 45 ust. 1 Konstytucji Rzeczypospolitej Polskiej z dnia 2 kwietnia 1997 r. (Dz.U. z 1997 r. Nr 78, poz. 483 ze zm.), zgodnie z którym każdy ma prawo do sprawiedliwego i jawnego rozpatrzenia sprawy bez nieuzasadnionej zwłoki przez właściwy, niezależny, bezstronny i niezawisły sąd.
} 
również uczestników do aktywnego podejmowania czynności w toku postępowania. Trzeba też dodać, że aktywna partycypacja uczestników, często reprezentowanych przez profesjonalnych pełnomocników procesowych powinna zmierzać do osiągnięcia celu postępowania, jakim pozostaje ustalenie i zatwierdzenie tabel wynagrodzeń. Wszelka więc bierność i zwłoka w realizacji czynności w toku postępowania, a nawet destrukcja postępowania nadużywaniem zbędnej argumentacji, czy w skrajnych przypadkach podejmowania próby dowodzenia okoliczności bezspornych pozostaje w omawianym postępowaniu pod ryzykiem umorzenia postępowania i narażenia uczestników na konieczność kontynuacji postępowania przed sądem powszechnym. Realna możliwość redukcji czasu i kosztów postępowań prowadzonych przed zespołami orzekającymi Komisji winna być doceniona zarówno przez uczestników postępowań, jak też korzystających z obrotu prawami autorskim uczestników, którzy nie biorą udziału w postępowaniu, ale są zobligowani do zawierania umów przy wykorzystaniu stawek wynagrodzeń ustalonych w zatwierdzanych tabelach.

W powołanym wyroku Trybunał Konstytucyjny obok konieczności zapewnienia pełnej ochrony prawnej $\mathrm{w}$ ramach prowadzenia postępowania $\mathrm{w}$ przedmiocie zatwierdzenia tabel wynagrodzeń wskazał na istotność kształtowania społecznej gospodarki rynkowej w oparciu o dialog i współpracę partnerów społecznych zgodnie $\mathrm{z}$ art. 20 Konstytucji. ${ }^{17} \mathrm{~W}$ pełni należy podzielić wywód przedstawiony w uzasadnieniu wyroku, iż w postępowaniu o zatwierdzenie tabel nie chodzi tylko o swobodę działalności gospodarczej, w tym swobodę kształtowania stawek tabel wynagrodzeń na rynku, lecz także o to, by mający z natury przeciwstawne interesy uczestnicy obrotu mogli ze sobą współdziałać dla ukształtowania się właściwego ładu gospodarczego, w myśl którego ochrony wymagają nie tylko interesy jednej ze stron, ale obu stron. Wyeksponowana idea współdziałania i współpracy partnerów obrotu prawami autorskimi koresponduje z zapewnieniem powszechnego dostępu do dóbr kultury, nauki i sztuki. Tylko bowiem efektywna współpraca przejawiana $\mathrm{w}$ toku procedowania $\mathrm{w}$ przedmiocie zatwierdzenia tabel pozostaje gwarancją osiągnięcia zamierzonego celu w postaci ustalenia obowiązujących stawek, w poczuciu realizacji nie tylko swobody umownego kształtowania wysokości tych stawek, ale również rynkowej stabilizacji wzajemnych relacji gospodarczych twórców i użytkowników korzystających $\mathrm{z}$ ich praw. Powyższe znajduje potwierdzenie również w akceptacji rozstrzygnięcia zespołu orzekającego Komisji, z wykluczeniem konieczności kontynuacji postępowania w ramach sądownictwa powszechnego. Aktywny udział w postępowaniu i akceptacja orzeczeń stanowią o pokojowym sposobie rozstrzygania sporów, które to rozwiązanie powszechnie przyjmowane jest przykładowo w międzynarodowym arbitrażu, z tendencją podmiotów handlu międzynarodowego do 
ucieczki od sądownictwa państwowego w kierunku arbitrażu i innych alternatywnych metod rozwiązywania sporów. ${ }^{18}$

$\mathrm{Z}$ ideą dialogu społecznego i współpracy partnerów obrotu prawami autorskimi koresponduje również wprowadzony do ustawy o prawie autorskim przepis art. $110^{18}$ pr. aut. przewidujący możliwość rozpatrywania sporów dotyczących stosowania zatwierdzonych prawomocnie tabel wynagrodzeń w drodze postępowania mediacyjnego między stronami, ze wskazaniem stosowania odpowiednio przepisów Kodeksu postępowania cywilnego o mediacji. Właśnie stosowanie alternatywnych metod rozwiązywania sporów (w skrócie określanych $\mathrm{ADR}^{19}$ ), przedstawianych również jako możliwość alternatywnego rozstrzygania sporów względem wymiaru sprawiedliwości sprawowanego przez sądownictwo powszechne, okazuje się najbardziej akceptowanym sposobem rozwiązywania sporów w duchu współpracy opartej na wzajemnym zaufaniu i szacunku, będących „fundamentem podtrzymującym ludzkie społeczeństwo".

\section{Wnioski końcowe}

Podsumowując problematykę stosowania przepisów obejmujących procedowanie dotyczące zatwierdzania tabel wynagrodzeń $\mathrm{z}$ utworów lub przedmiotów praw pokrewnych w ramach postępowań prowadzonych przez zespoły orzekające Komisji należy podkreślić zgodność i spójność z tendencjami nowoczesnego rozstrzygania sporów.

W szczególności należy docenić możliwość procedowania w zakresie zatwierdzania tabel wynagrodzeń przez zespoły orzekające organu publicznego, jakim jest Komisja Prawa Autorskiego, umocowana przez ustawodawcę obowiązującymi przepisami ustawy o prawie autorskim do rozstrzygania spraw obejmujących między innymi zatwierdzanie tabel wynagrodzeń z utworów lub przedmiotów praw pokrewnych. Poszukiwanie instytucjonalnych rozwiązań w zakresie możliwości rozpatrywania określonych kategorii spraw przed ewentualnym wystąpieniem na drogę postępowania sądowego staje się w obecnych czasach nie tylko wyzwaniem w ramach ustawodawstw krajowych, ale również pozostaje w kręgu zainteresowania legislacji unijnej. Zgodnie $\mathrm{z}$ danymi statystycznymi opracowywanymi $\mathrm{w}$ ramach funkcjonowania Ministerstwa Sprawiedliwości i przedstawionymi w Raporcie

\footnotetext{
18 Por. A.W. Wiśniewski, Międzynarodowy arbitraż handlowy w Polsce, Warszawa 2011, s. 85 w zakresie przedstawienia danych potwierdzających, iż w obszarze stosunków międzynarodowych arbitraż staje się regułą, bowiem ocenia się współcześnie, iż nawet ok. 90\% międzynarodowych kontraktów zawiera klauzulę arbitrażową, a wyjątkowo rzadko spotyka się kontrakt szczególnie znacznej wartości pozbawiony regulacji sposobu rozstrzygania sporów lub zawierający klauzulę jurysdykcyjną przewidującą właściwość sądów określonego państwa.

Akronim ADR utworzony został od angielskiego wyrażenia alternative dispute resolution, co należy przetłumaczyć, jako „alternatywne metody rozwiązywania sporów”, do których zalicza się między innymi arbitraż, mediacje, negocjacje i koncyliacje.
} 
z działalności sądów powszechnych w latach 2010-2014 ${ }^{20}$ liczba spraw wpływających do poszczególnych jednostek organizacyjnych sądownictwa powszechnego pozostaje na ogromnym poziomie kilkunastu milionów spraw rocznie. Ogromny wpływ spraw ma zasadnicze znaczenie w zakresie ustalania terminów rozpoznawania poszczególnych kategorii spraw sądowych oraz długości trwania procedowania, które niestety pozostają dalekie od uzasadnionych oczekiwań stron i uczestników postępowań sądowych. Wszelkie więc rozwiązania organizacyjne, a szczególnie znajdujące odzwierciedlenie we wprowadzanych przepisach wychodzą naprzeciw realizacji „przedsądowego” lub „pozasądowego” rozstrzygania sporów. Inicjatywy w zakresie podnoszenia skuteczności wymiaru sprawiedliwości we wszystkich państwach członkowskich Unii Europejskiej promowane są również w ramach funkcjonowania wielu organów i instytucji na poziomie unijnym. ${ }^{21} \mathrm{~W}$ związku z powyższym przygotowywane i uchwalane są regulacje, zgodnie z którymi eksponuje się konieczność zapewnienia dostępu do prostych, skutecznych, szybkich i tanich sposobów rozstrzygania sporów krajowych i transgranicznych, w tym również wykorzystywania alternatywnych metod rozstrzygania sporów. ${ }^{22} \mathrm{~W}$ odniesieniu do wskazanych obiektywnych trudności w rozpoznawaniu spraw w ramach sądowego rozstrzygania sporów nie można zatem podzielić stanowiska wyrażanego w piśmiennictwie w zakresie ewentualnego zlikwidowania Komisji i przekazania spraw rozstrzyganych przed zespołami orzekającymi Komisji do rozstrzygnięcia w ramach sądownictwa powszechnego. ${ }^{23}$ Poszukiwanie optymalnego sposobu rozstrzygania sporów, przy zachowaniu gwarancji sprawności i jakości prowadzonych postępowań okazuje się zatem niezwykle istotne $w$ ramach zgodności ze standardami europejskimi, a przede wszystkim z oczekiwaniami uczestników postępowań pozasądowych i stron postępowań prowadzonych w ramach sądowego sprawowania wymiaru sprawiedliwości w odniesieniu do standardów procedowania oczekiwanych w demokratycznym państwie prawa.

Przedstawione i omówione przepisy ustawy o prawie autorskim dotyczące prowadzenia postępowania w zakresie zatwierdzania tabel wynagrodzeń $\mathrm{z}$ utworów lub przedmiotów praw pokrewnych przewidują wiele istotnych rozwiązań, które mają znaczenie i wpływ nie tylko na sprawność postępowania, ale również akceptację rozstrzygnięć kończących postępowanie w sprawie. W ramach rozwiązań uspraw-

20 Publikowanym na stronie internetowej: http://isws.ms.gov.pl/pl/baza-statystyczna/publikacje/ (data dostępu: 04.09.2015 r.).

21 Por. komunikat Komisji Europejskiej do Parlamentu Europejskiego, Rady Europejskiej, Europejskiego Banku Centralnego, Europejskiego Komitetu Ekonomiczno-Społecznego i Komitetu Regionów obejmujący unijną tablicę wyników wymiaru sprawiedliwości z 2015 r., publikowany http://ec.europa.eu/justice/effective-justice/files/justice_ scoreboard_2015_pl.pdf (data dostępu: 04.09.2015 r.).

22 Por. motyw 4 i n. oraz przepisy Dyrektywy Parlamentu Europejskiego i Rady 2013/11/UE z dnia 21 maja 2013 r. w sprawie alternatywnych metod rozstrzygania sporów konsumenckich oraz zmiany rozporządzenia (WE) nr 2006/2004 i dyrektywy 2009/22/WE, (Dz. Urz. UE L 165 z 18.06.2013, s. 63).

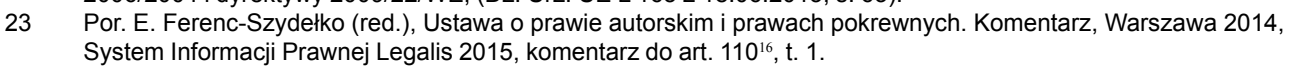


niających postępowanie należy wyeksponować ograniczenie czasu prowadzenia postępowania, jako mechanizmu dyscyplinującego zarówno prowadzący postępowanie zespół orzeczniczy Komisji, jak też uczestników postępowania w ramach ich aktywnej partycypacji w czynnościach realizowanych $\mathrm{w}$ toku postępowania. Podobnie reprezentatywność wyboru składu zespołu orzekającego Komisji z listy arbitrów Komisji, przy uwzględnieniu możliwości przedstawiania do Komisji kandydatów zgłaszanych przez organizacje reprezentujące zarówno twórców, jak też użytkowników korzystających z praw ma ogromne znaczenie dla aprobaty czynności realizowanych $w$ ramach prowadzenia postępowania i wspomnianej akceptacji rozstrzygnięć zespołów orzekających Komisji.

Wobec powyższego należy skonstatować, że w obszarze zarówno procedowania w zakresie zatwierdzania tabel wynagrodzeń, a szczególnie w sporach dotyczących stosowania zatwierdzonych prawomocnie tabel wynagrodzeń możliwe i wskazane jest stosowanie nowoczesnych pozasądowych metod rozwiązywania i rozstrzygania sporów, pozostających w zgodności ze standardami najnowszej legislacji unijnej, w tym z regulacjami mającymi na celu zapewnienie koordynacji krajowych przepisów dotyczących warunków podejmowania działalności w zakresie zarządzania prawami autorskimi i prawami pokrewnymi przez organizacje zbiorowego zarządzania celem między innymi zapewnienia wysokiego poziomu zarządzania, przejrzystości i sprawozdawczości, z korzyścią dla twórców oraz użytkowników. ${ }^{24}$

24 Por. motywy dyrektywy Parlamentu Europejskiego i Rady 2014/26/UE z dnia 26 lutego 2014 r. w sprawie zbiorowego zarządzania prawami autorskimi i prawami pokrewnymi oraz udzielania licencji wieloterytorialnych dotyczących praw do utworów muzycznych do korzystania on-line na rynku wewnętrznym (Dz. Urz. UE L 84/72 z 20.03.2014 r.). 


\section{PROCEDURE OF APPROVING THE TABLES OF REMUNERATION FOR THE USE OF OBJECTS OF COPYRIGHT AND RELATED RIGHTS FROM THE MODERN LITIGATION PERSPECTIVE}

The paper includes the presentation and discussion on the proceeding rules regarding the approval of the remuneration tables for the use of objects of copyright and related rights within proceedings conducted by adjudicating panels of the Copyright Commission in accordance with the provisions of the Act on Copyright and Related Rights of 4 February 1994.

The Copyright Commission conducts the proceedings essentially based on the provisions amended by the Constitutional Tribunal in its judgment of 24 January 2006 case file SK 40/04, in which it ruled on the unconstitutionality of Article 108(3) of the aforementioned Act on Copyright regarding proceedings before the Commission on the approval of the remuneration tables for the use of objects of copyright or performances submitted by collective management organizations. As a result of the amendment, the binding regulations provide for defining the scope of proceeding before the Commission on the approval of rates submitted by collective management organizations with ensuring, in case of contesting a Commission's decision, the possibility to continue the proceedings before a general court. In the legislation the participation of parties in determining the composition of the adjudicating panel of the Commission, the introduction of restrictions on the length of proceedings and the opportunity to challenge a decision of the adjudicating panel of the Commission by filing a relevant application to the participant and to submit the case to court were exposed.

In the assessment of the proceeding concerning the approval of remuneration tables for objects of copyright or related rights, its consistency and compatibility with the concepts of the modern settlement of disputes were indicated. Additionally, the compliance of the provisions with the EU law standards laid down in the latest EU legislation was underlined, including regulations aimed at ensuring the coordination of national provisions concerning the conditions for copyright and related rights management by collective management organizations to ensure a high level of management, transparency and reporting according to the objectives of Directive 2014/26/EU of the European Parliament and of the Council of 26 February 2014 on collective management of copyright and related rights and multi-territorial licensing of rights in musical works for online use in the internal market.

It can be concluded that it is possible and desirable to use the modern alternative methods of dispute resolution in the area of proceeding on the approval 
of remuneration tables, particularly in disputes concerning the application of the approved remuneration tables.

Słowa kluczowe: prawo autorskie, organizacje zbiorowego zarządzania, zatwierdzanie tabel wynagrodzeń, Komisja Prawa Autorskiego, nowoczesne rozstrzyganie sporów, alternatywne metody rozstrzygania sporów, pozasądowe prowadzenie postępowań

Keywords: the Copyright Commission, copyright and related rights, approval of remuneration tables, proceedings before a general court, collective management organizations, Directive 2014/26/EU, alternative dispute resolutions, modern litigation 